\title{
Synthesis of $\mathrm{CaF}_{2}-\mathrm{YF}_{3}$ nanopowders by co-precipitation from aqueos solutions
}

\author{
P. P. Fedorov ${ }^{1}$, M. N. Mayakova ${ }^{1}$, S. V. Kuznetsov ${ }^{1}$, V. V. Voronov ${ }^{1}$, Yu. A. Ermakova ${ }^{1}$, A. E. Baranchikov ${ }^{2}$ \\ ${ }^{1}$ A. M. Prokhorov General Physics Institute, Russian Academy of Sciences \\ 38 Vavilov Street, Moscow, 119991, Russia \\ ${ }^{2}$ N. S. Kurnakov Institute of General and Inorganic Chemistry, \\ Russian Academy of Sciences, Leninskii pr. 31, Moscow, 119991, Russia \\ ppfedorov@yandex.ru
}

DOI 10.17586/2220-8054-2017-8-4-462-470

\begin{abstract}
Study of the $\mathrm{CaF}_{2}-\mathrm{YF}_{3}$ system by co-precipitation from aqueous nitrate solutions revealed the formation of $\mathrm{Ca}_{1-x} \mathrm{Y}_{x} \mathrm{~F}_{2+x}$ solid solution precipitate containing up to $20 \mathrm{~mol}$ \% yttrium fluoride $(x \leq 0.2)$. A higher yttrium to calcium ratio in the starting solutions caused additional precipitation of orthorhombic $\beta-\mathrm{YF}_{3}$ nanophase elongated along the $\langle b\rangle$ axis. Cubic $\left(\mathrm{H}_{3} \mathrm{O}\right) \mathrm{Y}_{3} \mathrm{~F}_{10}$ phase was also formed (SSG Fm3m, $a=$ $11.60 \AA, \mathrm{KY}_{3} \mathrm{~F}_{10}$ structural type).
\end{abstract}

Keywords: calcium fluoride, yttrium fluoride, nanopowders.

Received: 19 July 2017

Revised: 2 August 2017

\section{Introduction}

The $\mathrm{CaF}_{2}-\mathrm{YF}_{3}$ system, along with the $\mathrm{NaF}-\mathrm{YF}_{3}$ system [1-4], plays a particularly important role among binary fluoride systems. Solid solution of yttrium fluoride in calcium fluoride is a classic example of heterovalent isomorphism [5]. Its study was initially discussed by Vogt in treatises on yttrofluorite [6], and has continued for more than a hundred years [7-24] (for a more detailed history of this study, please see [18]): the said $\mathrm{CaF}_{2}-$ $\mathrm{YF}_{3}$ system has become a model for describing the interaction of calcium fluoride with the rare earth fluorides from yttrium group of elements (see Fig. 1). The $\mathrm{CaF}_{2}-\mathrm{YF}_{3}$ system is also the basis for several natural fluoride minerals $[6,15,25-27]$.

Yttrium cation substitutes calcium ions in the fluorite structure, and supplementary fluoride anions, penetrating the formed crystal lattice, compensate for the corresponding changes in electrostatic charges for the sake of electrical neutrality of the system. The formed cationic and anionic defects associate among themselves, thus forming defect clusters [28,29]. $\mathrm{Ca}_{1-x} \mathrm{Y}_{x} \mathrm{~F}_{2+x}$ solid solution maintains its original fluorite-type structure within the $0 \leq x \leq 0.38$ interval limits. A smooth maximum in the melting curves of $\mathrm{Ca}_{1-x} \mathrm{Y}_{x} \mathrm{~F}_{2+x}$ at $x=0.11$ (Fig. 1) allows the growth of high-quality $\mathrm{Ca}_{1-x} \mathrm{Y}_{x} \mathrm{~F}_{2+x}$ single crystals from its melts with $x \leq 0.15$.

Such synthetic $\mathrm{Ca}_{1-x} \mathrm{Y}_{x} \mathrm{~F}_{2+x}$ yttrofluorite crystals have become widely used photonics materials, including solid state laser matrices [13]. Also, introducing yttrium fluoride into the calcium fluoride crystal lattice causes dramatic changes in its physical properties, including fluoride-ion ionic conductivity, hardness, cleavage and heat conductivity (the latter two parameters decrease significantly) [23,30]. Relatively high yttrium concentrations complicate $\mathrm{Ca}_{1-x} \mathrm{Y}_{x} \mathrm{~F}_{2+x}$ single crystal growth from the melts due its incongruent melting, and the formation of a cellular substructure [31,32], and local ordering of the formed solid solution [7, 12]. Additional increase in the $\mathrm{YF}_{3}$ content in the $\mathrm{CaF}_{2}-\mathrm{YF}_{3}$ system leads to the formation of another berthollide-type variable-composition solid solution at $65-75 \mathrm{~mol} . \% \mathrm{YF}_{3}$ with hexagonal $\mathrm{LaF}_{3}$ tysonite-type structure [10,11]. This phase undergoes metastable ordering under cooling. Another solid solution, based on high-temperature $\alpha-\mathrm{YF}_{3}$ polymorph, is also formed in the $\mathrm{CaF}_{2}-\mathrm{YF}_{3}$ system [33].

Fedorov [21] reported the lower temperature part of the phase diagram of the $\mathrm{CaF}_{2}-\mathrm{YF}_{3}$ system, taking into account the results for Kuntz's [15] hydrothermal studies and Bergstol et al. [25] investigation of tveitite mineral formation under natural conditions (tveitite is an ordered fluorite-type phase), and considering that fluorite-type solid solutions undergo ordering with the formation of a series of fluorite-type phases when cooled [4,12]. The latter fluorite-type phases contain $\mathrm{Y}_{6} \mathrm{~F}_{37}$ clusters in their crystal lattices with Thompson antiprism coordination yttrium polyhedra. Such clusters fit in naturally in the fluorite crystal lattice (Fig. 2) and appear to be the dominant type of structural defects in $\mathrm{Ca}_{1-x} \mathrm{Y}_{x} \mathrm{~F}_{2+x}$ solid solutions at higher yttrium concentrations [14,16,28,29]. The heterovalent substitution mechanism for the formation of the aforementioned solid solutions (Fig. 2) can be described by the following equation:

$$
\left(\mathrm{M}_{6} \mathrm{~F}_{32}\right)^{20-} \rightarrow\left(\mathrm{Y}_{6} \mathrm{~F}_{37}\right)^{19-}+\mathrm{F}_{\text {int }}^{-}
$$




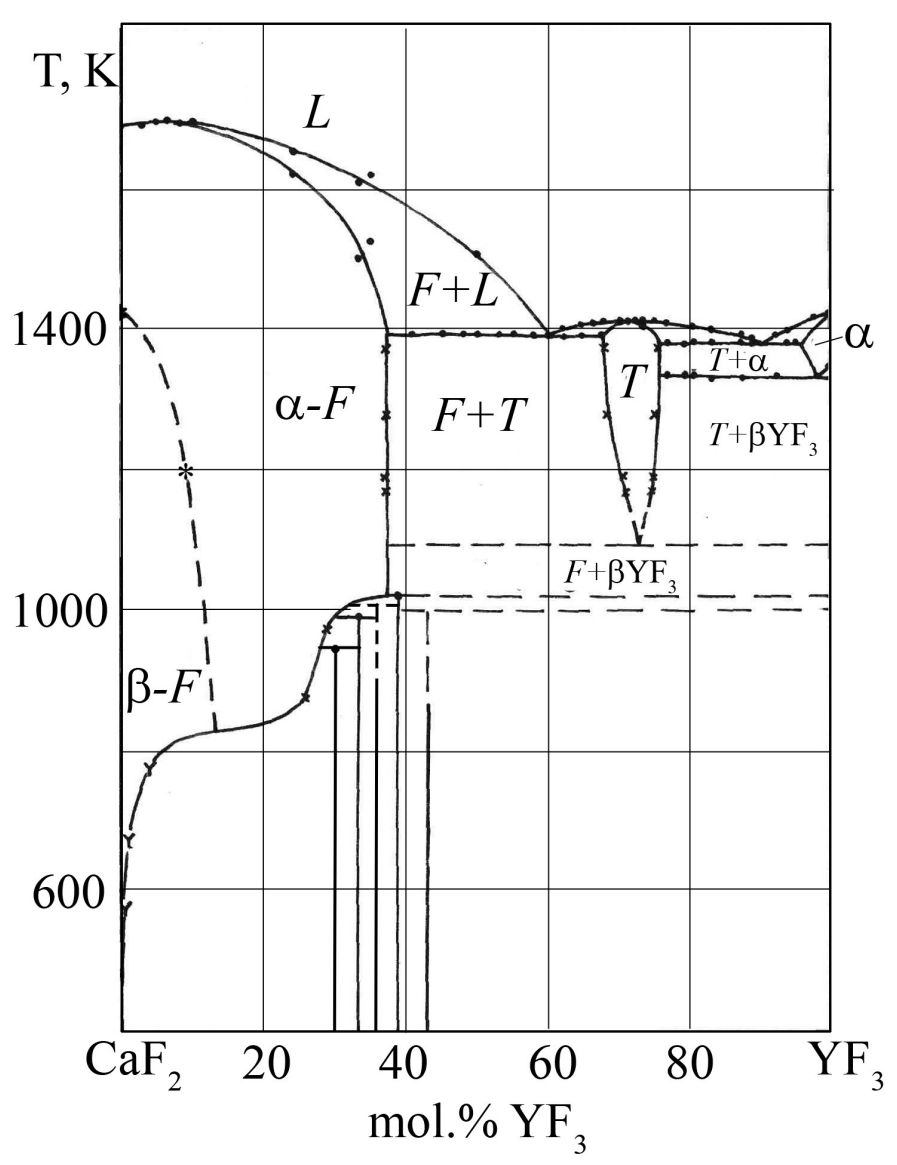

FIG. 1. Phase diagram of the $\mathrm{CaF}_{2}-\mathrm{YF}_{3}$ system [17]. $L-$ melt, $F-\mathrm{Ca}_{1-x} \mathrm{Y}_{x} \mathrm{~F}_{2+x}$ fluorite-type solid solution, $T$ - tysonite $\left(\mathrm{LaF}_{3}\right)$ type berthollide phase
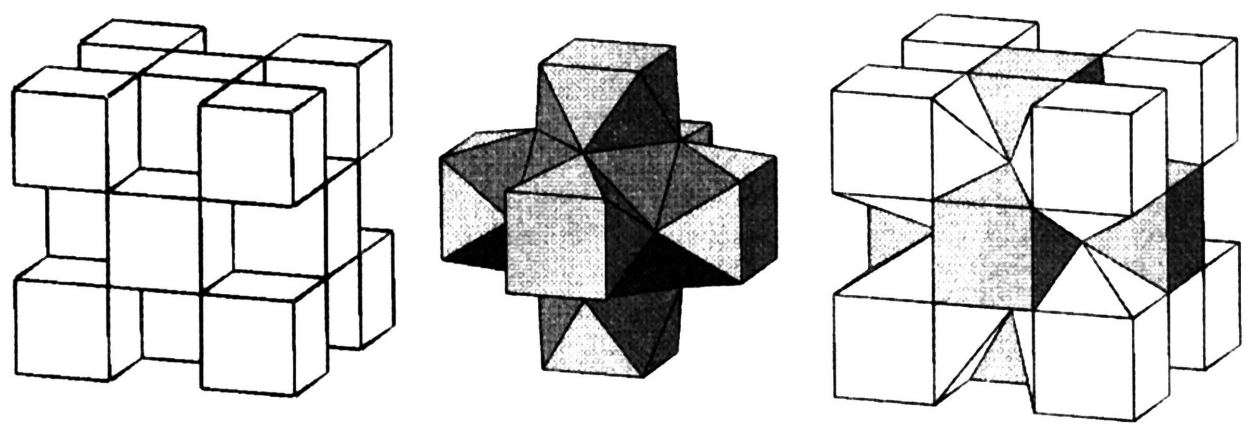

FIG. 2. Insertion of $\mathrm{R}_{6} \mathrm{~F}_{37}$ clusters into the fluorite matrix

Nanofluorides are another rapidly developing area of the modern science [34-39], for nanofluorides are widely implemented as luminophores, catalysts, biomedical and electrochemical materials; the $\mathrm{CaF}_{2}-\mathrm{YF}_{3}$ system has also become crucially important in this area, as well. Low-temperature and soft chemistry syntheses of nanofluorides (e.g, mechanochemical [40,41], sol-gel [24], solvothermal [42] methods and some other techniques [35]) are especially prominent because of their technological advantages. Recently, we have successfully used our coprecipitation from aqueous solutions methods for nanofluoride preparations [34,35,43-48], including our systematic studies of phase formations in the $\mathrm{BaF}_{2}-\mathrm{YF}_{3}$ [49], $\mathrm{BaF}_{2}-\mathrm{BiF}_{3}$ [50], $\mathrm{BaF}_{2}-\mathrm{ScF}_{3}$ [51], $\mathrm{BaF}_{2}-\mathrm{CeF}_{3}[52], \mathrm{SrF}_{2}-$ $\mathrm{YF}_{3}$ [53] and $\mathrm{CaF}_{2}-\mathrm{HoF}_{3}$ [54] systems. We have observed varieties of phase fields in the studied $\mathrm{MF}_{2}-\mathrm{YF}_{3}$ and $\mathrm{NaF}-\mathrm{RF}_{3}$ systems, including non-equilibrium phases with wide areas of homogeneity; we have also observed the absence of the ordered phases that exist under higher temperature equilibrium conditions [4]. 
Thus, according to the background given above, the purpose of the present study was the investigation of nanophase formation in the $\mathrm{CaF}_{2}-\mathrm{YF}_{3}$ system under co-precipitation from aqueous solutions at lower temperatures.

\section{Experimental}

We used 99.99 wt.\% pure $\mathrm{Y}\left(\mathrm{NO}_{3}\right)_{3} \cdot 6 \mathrm{H}_{2} \mathrm{O}$ and $\mathrm{Ca}\left(\mathrm{NO}_{3}\right)_{2} \cdot 4 \mathrm{H}_{2} \mathrm{O}$ (manufactured by $\mathrm{OOO}$ Lanchit), as well as $99.9 \%$ pure 40 wt.\% aqueous HF (manufactured by TECH System) and double distilled water as starting materials without any further purification.

Specimens in the $\mathrm{CaF}_{2}-\mathrm{YF}_{3}$ system were prepared by co-precipitation from aqueous solutions in polypropylene reactors according to previously-described procedures $[4,49,53,54] .0 .2 \mathrm{Mol} / \mathrm{L}$ aqueous nitrate solutions in double distilled water were vigorously mixed with magnetic stirring bar and then added dropwise under continued stirring to a 2 -fold excess of 5 vol.\% aqueous HF. The formed precipitates were decanted, rinsed with double distilled water until a $\mathrm{pH}$ of 5-6 was obtained. In some experiments, precipitates were additionally neutralized with aqueous ammonia (99.9\% pure) and then rinsed again with double distilled water until a $\mathrm{pH}$ of 5-6 was maintained. All precipitates were air-dried at $40{ }^{\circ} \mathrm{C}$.

Phase composition of the synthesized samples was characterized by X-ray powder diffraction (Bruker D8 diffractometer; $\mathrm{CuK}_{\alpha}$ radiation; TOPAS software package for experimental data treatment and coherent scattering domain and microdeformation size calculations). Particle dispersity and morphology were controlled by scanning electron microscopy (SEM) (NVision 40 microscope). The same NVision 40 microscope was also used for the sample chemical analyses (X-ray spectroscopy). Specimen chemical composition was also studied by atomic emission spectroscopy (AES) with the use of LEA-S500 analyzer (OOO SOL Instruments, Minsk, Belarus) (see Supporting Information for the further details). MOM Q-1500D PaulikPaulikErdey derivatograph has been utilized for the thermal analysis investigations (Pt crucibles, air).

\section{Results and Discussion}

Colloid solutions in the $\mathrm{CaF}_{2}-\mathrm{YF}_{3}$ system were obtained during the synthesis in which the precipitate formed very slowly (couple of weeks) (Figs. 3-7; Tables 1, 2). SEM data (Fig. 3) confirmed that the precipitated nanoparticles were actually of the small sizes. Chemical analyses of both types, X-ray spectroscopy and AES (Table 1, also see Supplemental Information), have shown that the metal ratios in the formed solid precipitates were close to the corresponding ratios in the starting aqueous solutions/mixtures even if the observed ratio differences were a little bit larger than in the case of the previously studied $\mathrm{SrF}_{2}-\mathrm{YF}_{3}$ [53] and $\mathrm{BaF}_{2}-\mathrm{YF}_{3}$ [49] systems.

$\mathrm{X}$-Ray diffraction data indicated that precipitates formed from solutions with $20 \mathrm{~mol} \% \mathrm{YF}_{3}$ or less were $\mathrm{CaF}_{2}$-based fluorite-type solid solutions (cubic system, $\mathrm{Fm} 3 \mathrm{~m}$ SSG). SEM image of the $10 \mathrm{~mol} . \mathrm{Y} \mathrm{YF}_{3}$ specimen (i.e., precipitated from the $10 \% \mathrm{Y}^{3+}$ and $90 \% \mathrm{Ca}^{2+}$ solution) contained readily-visible/resolved agglomerates of the same phase particles $30-50 \mathrm{~nm}$ in diameter. Experimental data for the unit lattice parameters of precipitated $\mathrm{Ca}_{1-x} \mathrm{Y}_{x} \mathrm{~F}_{2+x}$ solid solutions coincided within the $0.004 \AA$ range with the $a(\mathrm{x})$ concentration dependency function for $\mathrm{Ca}_{1-x} \mathrm{Y}_{x} \mathrm{~F}_{2+x}$ solid solutions, synthesized at higher temperatures [55] (Fig. 7). However, in addition to the increasing crystal lattice parameter, X-ray diffraction patterns of precipitates $\mathrm{Ca}_{1-x} \mathrm{Y}_{x} \mathrm{~F}_{2+x}$ contained weak (200) lines at about $32.5^{\circ} 2 \theta$ (this line is absent in the $\mathrm{X}$-ray diffraction pattern of the pure face-centered $\mathrm{CaF}_{2}$ ). The latter observation was an additional evidence of the solid solution formation.

$\mathrm{X}$-Ray diffraction patterns of $\mathrm{Ca}_{1-x} \mathrm{Y}_{x} \mathrm{~F}_{2+x}$ samples with 30 mol. \% or more $\mathrm{YF}_{3}$ contained broadened lines of $\beta-\mathrm{YF}_{3}$ nanoparticles (orthorhombic system, Pnma SSG [18]) (Figs. 4-5). However, relative clarity of (020) $\beta-\mathrm{YF}_{3}$ line at about $26^{\circ} 2 \theta$ indicated that crystal lattices of the said $\beta-\mathrm{YF}_{3}$ nanoparticles were stretched along $\langle b\rangle$ axis.

All precipitated fluorides were hydrated and contained about $5.5 \pm 0.3$ wt. \% water (DTA data, see Supplemental Information). Heating of these specimens was accompanied with mass losses that continued to $450-500{ }^{\circ} \mathrm{C}$. X-Ray diffraction patterns of such samples annealed at $450-500{ }^{\circ} \mathrm{C}$ contained only narrowed lines, and the latter phenomenon was an unequivocal evidence of the nanoparticle enlargement.

Synthesis of the $90 \% \mathrm{YF}_{3}-10 \% \mathrm{CaF}_{2}$ solid solution resulted in the formation of the novel phase (Fig. 4) with the X-ray diffraction pattern indexed in the $P$-cubic system with $a=5.800(2) \AA$ parameter (Table 2) or in the F-cubic system with $a=11.60 \AA$ (calculated size of the coherent scattering domain $D=25 \mathrm{~nm}$ ). The SEM image of this specimen contained joined together plate-type nanocrystals (Figs. 3c and 3d).

The X-Ray diffraction pattern of this phase was similar to the one of $\mathrm{KY}_{3} \mathrm{~F}_{10}(F m 3 m \mathrm{SSG}, Z=8$ ), so one could assume that it was $\left(\mathrm{H}_{3} \mathrm{O}\right) \mathrm{Y}_{3} \mathrm{~F}_{10}$ compound with hydroxonium ions occupying potassium sites in the crystal lattice. Heating the specimen resulted in about 11.3 wt. \% mass loss (Supplemental Information), which might 


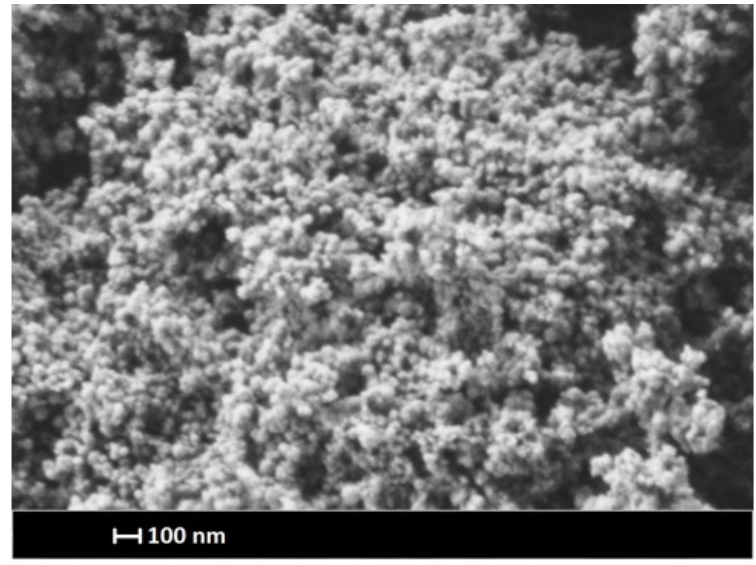

a

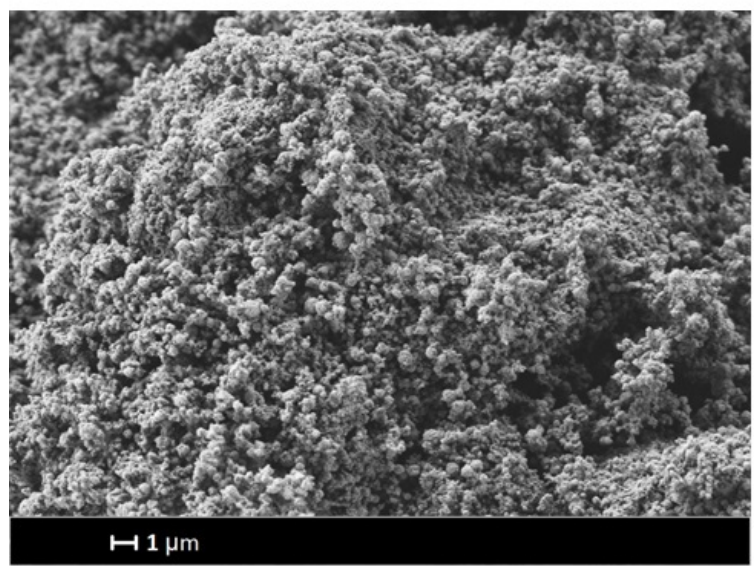

c

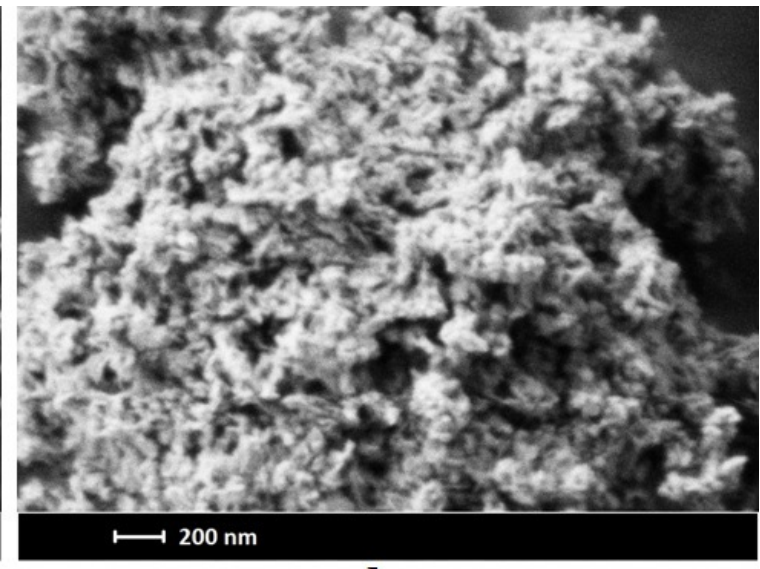

b

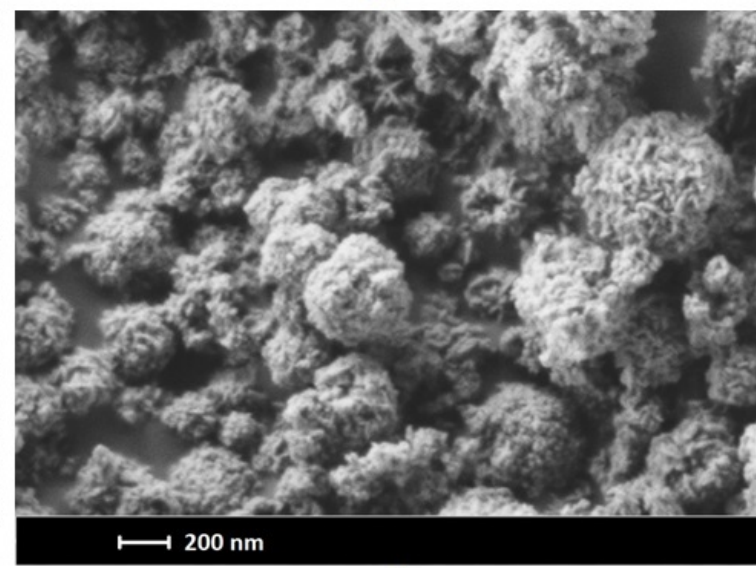

d

FIG. 3. SEM images of the $\mathrm{CaF}_{2}-\mathrm{YF}_{3}$ specimens: $10 \mathrm{~mol}$. $\% \mathrm{YF}_{3}$ (a), $50 \% \mathrm{~mol} . \mathrm{YF}_{3}$ (b), $90 \% \mathrm{~mol}_{0} \% \mathrm{YF}_{3}(\mathrm{c}, \mathrm{d})$

TABLE 1. Chemical analysis of $\mathrm{CaF}_{2}-\mathrm{YF}_{3}$ specimens

\begin{tabular}{|c|c|c|c|}
\hline \multirow{2}{*}{ Sample composition } & \multicolumn{3}{|c|}{ Refined $\mathrm{YF}_{3}$ content, mol. \% } \\
\cline { 2 - 4 } & $\begin{array}{c}\text { X-Ray spectroscopy } \\
\text { (electron microscopy) }\end{array}$ & $\begin{array}{c}\text { Atomic emission spectroscopy (AES) } \\
\text { 290 nm excitation } \\
\text { wavelength }\end{array}$ & $\begin{array}{c}320 \mathrm{~nm} \text { excitation } \\
\text { wavelength }\end{array}$ \\
\hline $\begin{array}{c}\mathrm{Ca}_{0.70} \mathrm{Y}_{0.30} \mathrm{~F}_{2.30} \\
\left(30.0 \mathrm{~mol} \% \% \mathrm{YF}_{3}\right)\end{array}$ & - & $26.06 \pm 0.75$ & $25.85 \pm 0.92$ \\
\hline $\begin{array}{c}\mathrm{Ca}_{0.50} \mathrm{Y}_{0.50} \mathrm{~F}_{2.50} \\
\left(50.0 \mathrm{~mol}_{0} \mathrm{YF}_{3}\right)\end{array}$ & 52.4 & $52.01 \pm 1.69$ & $54.14 \pm 1.85$ \\
\hline $\begin{array}{c}\mathrm{Ca}_{0.30} \mathrm{Y}_{0.70} \mathrm{~F}_{2.70} \\
\left(70.0 \mathrm{~mol} \% \% \mathrm{YF}_{3}\right)\end{array}$ & - & $68.83 \pm 2.16$ & $73.31 \pm 1.41$ \\
\hline $\begin{array}{c}\mathrm{Ca}_{0.10} \mathrm{Y}_{0.90} \mathrm{~F}_{2.90} \\
\left(90.0 \mathrm{~mol} \% \mathrm{YF}_{3}\right)\end{array}$ & 90.8 & - & \\
\hline
\end{tabular}




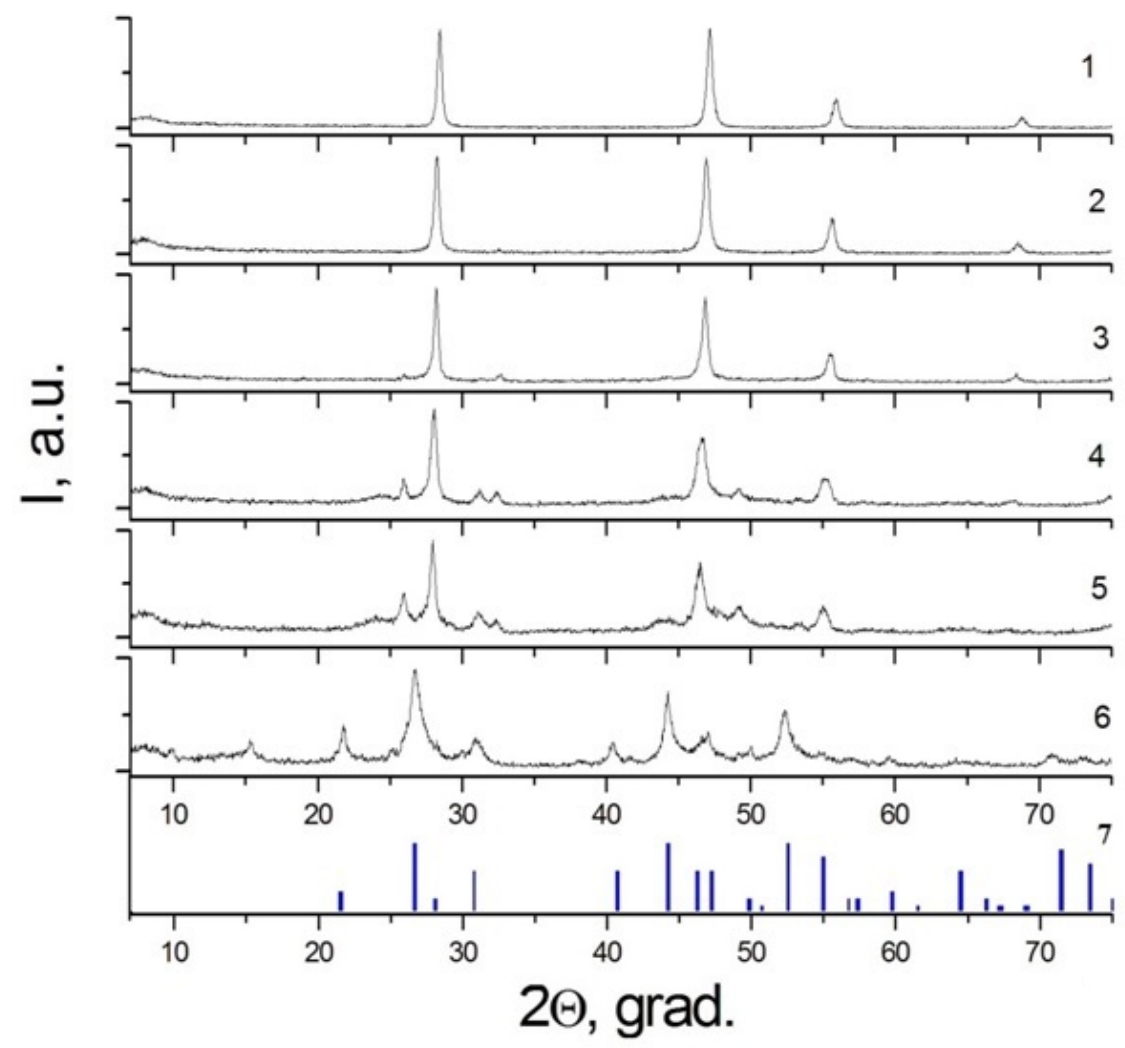

FIG. 4. X-Ray powder diffraction patterns for the specimens obtained by co-precipitation of calcium and yttrium fluorides from aqueous nitrate solutions: $10 \mathrm{~mol} \%$ (1); $20 \mathrm{~mol} \%$ (2); 30 mol.\% (3); 50 mol.\% (4); 70 mol.\% (5); 90 mol.\% (6) $\mathrm{YF}_{3}$ (nominal compositions), and JCPDS Card No. 27-0465 for $\mathrm{KY}_{3} \mathrm{~F}_{10}$ phase (7)

TABLE 2. X-Ray diffraction pattern of the $\mathrm{Ca}_{0.10} \mathrm{Y}_{0.90} \mathrm{~F}_{2.90}$ specimen $\left(Q=10^{4} / d^{2}\right.$. P-cubic lattice, $a=5.800(2) \AA, F(14)=11.9, M(14)=25.8$ )

\begin{tabular}{|c|c|c|c|c|c|c|c|}
\hline$N$ & $2 O(\mathrm{obs})$ & $d(\mathrm{obs}), \AA$ & $Q$ (obs) & $I / I_{0}, \%$ & h k 1 & $Q($ calc $)$ & $\Delta Q$ \\
\hline 1 & 15.320 & 5.7789 & 299.44 & 15 & 100 & 297.25 & 2.19 \\
\hline 2 & 21.730 & 4.0866 & 598.79 & 39 & 110 & 594.50 & 4.29 \\
\hline 3 & 26.740 & 3.3312 & 901.15 & 100 & 111 & 891.75 & 9.40 \\
\hline 4 & 30.900 & 2.8915 & 1196.06 & 15 & 200 & 1189.00 & 7.06 \\
\hline 5 & 38.020 & 2.3648 & 1788.18 & 5 & 211 & 1783.50 & 4.68 \\
\hline 6 & 44.240 & 2.0457 & 2389.55 & 75 & 220 & 2378.00 & 11.55 \\
\hline 7 & 47.000 & 1.9318 & 2679.64 & 30 & 221 & 2675.25 & 4.38 \\
\hline 8 & 52.350 & 1.7463 & 3279.16 & 50 & 311 & 3269.75 & 9.40 \\
\hline 9 & 54.740 & 1.6755 & 3562.14 & 10 & 222 & 3567.00 & -4.86 \\
\hline 10 & 59.530 & 1.5516 & 4153.75 & 7 & 321 & 4161.50 & -7.75 \\
\hline 11 & 64.170 & 1.4502 & 4754.93 & 3 & 400 & 4756.01 & -1.07 \\
\hline 12 & 70.820 & 1.3294 & 5658.34 & 8 & 331 & 5647.76 & 10.58 \\
\hline 13 & 72.810 & 1.2979 & 5936.32 & 5 & 420 & 5945.01 & -8.68 \\
\hline
\end{tabular}




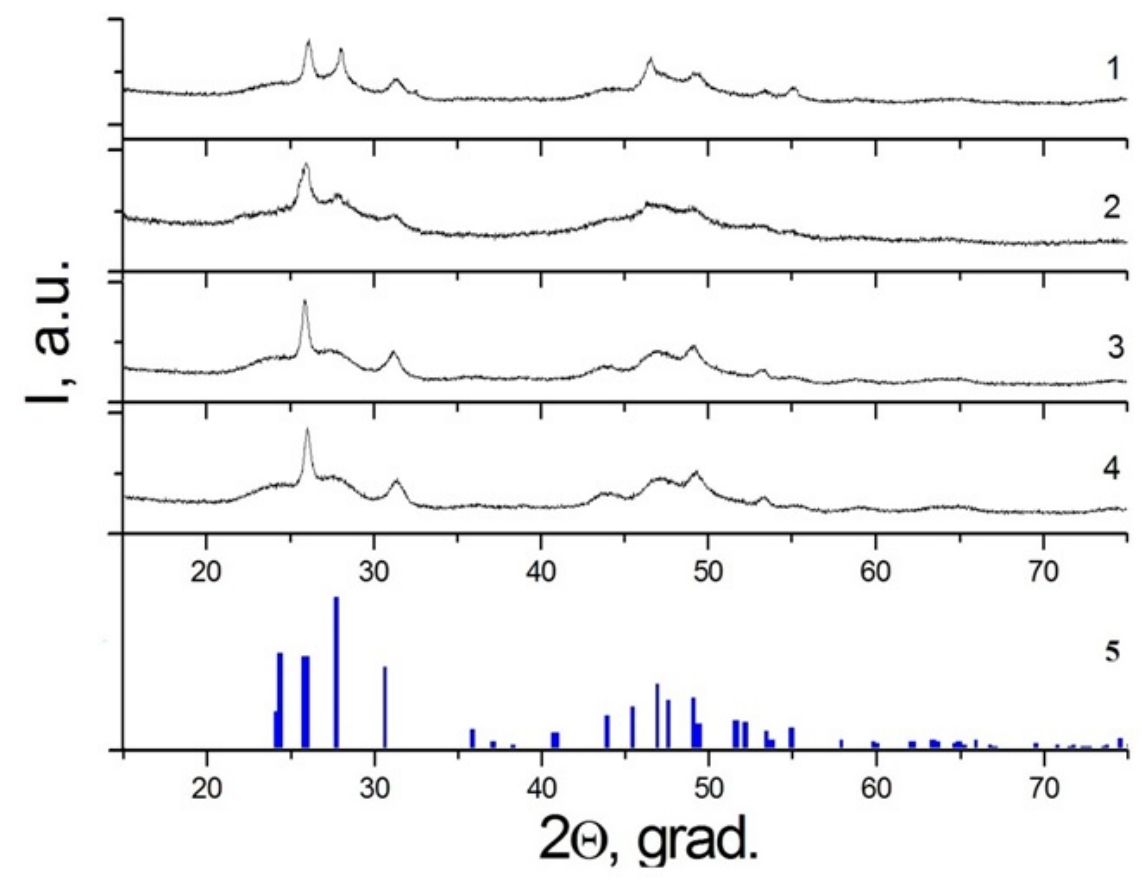

FIG. 5. X-Ray powder diffraction patterns for the specimens obtained by co-precipitation of calcium and yttrium fluorides from aqueous nitrate solutions (second set of experiments): 80 mol.\% (1), 85 mol. \% (2), 90 mol. \% (3), 95 mol.\% (4), and JCPDS Card No. 74-0911 for $\beta-\mathrm{YF}_{3}$ phase (5)

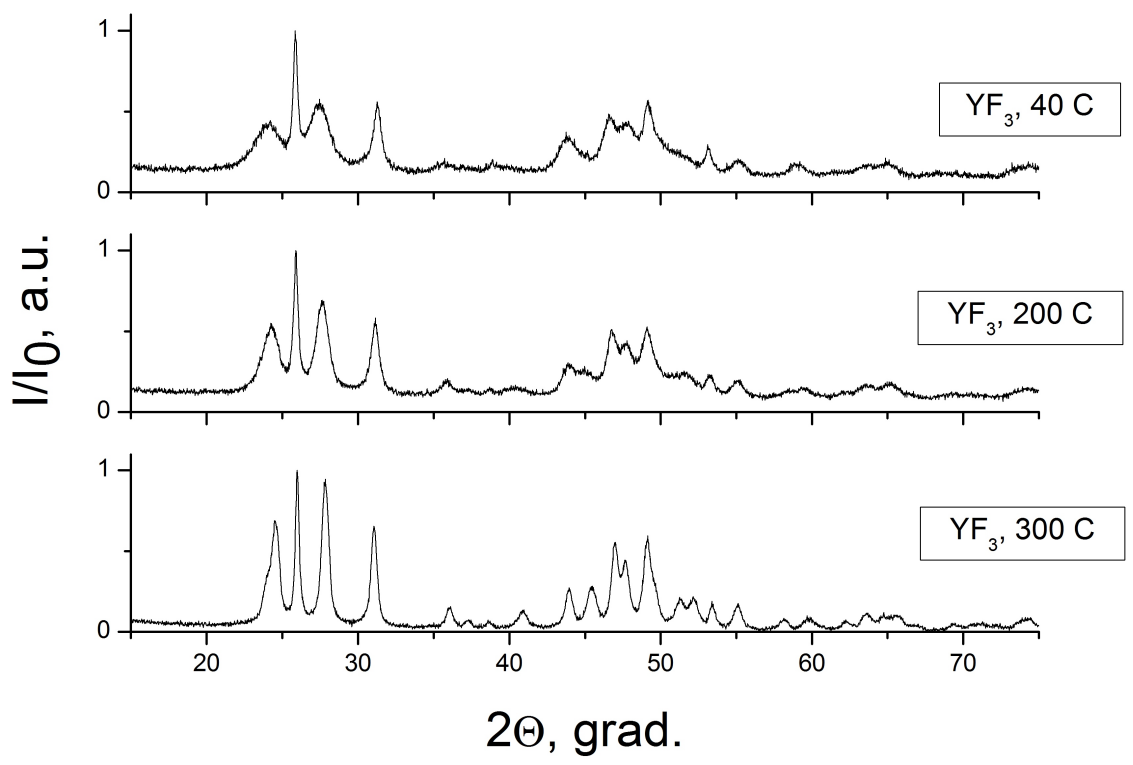

FIG. 6. X-Ray powder diffraction patterns for the $\mathrm{YF}_{3}$ specimens: freshly prepared, $a=6.294(3), b=6.867(4), c=4.528(3) \AA(1)$, annealed at $200{ }^{\circ} \mathrm{C}, a=6.317(2), b=6.875(2)$, $c=4.469(2) \AA(2), \mathrm{YF}_{3}$ annealed at $300{ }^{\circ} \mathrm{C}, a=6.346(1), b=6.861(1), c=4.419(1) \AA(3)$ 


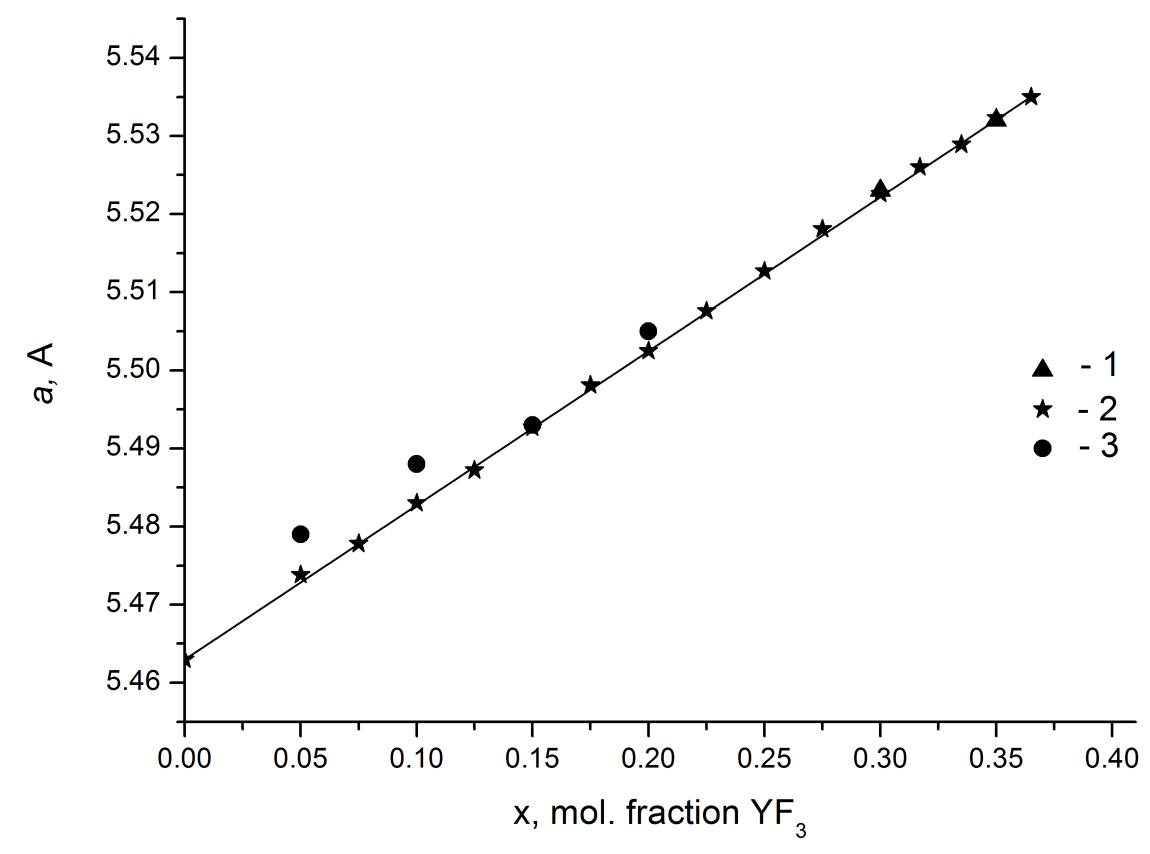

FIG. 7. Unit cell parameters for $\mathrm{Ca}_{1-x} \mathrm{Y}_{x} \mathrm{~F}_{2+x}$ fluorite-type solid solutions as per Fedorov et al. [7] (1) and Gettmann and Greis [12] (2), (all specimens were synthesized by solid phase synthesis) along with the present work data for $\mathrm{Ca}_{1-x} \mathrm{Y}_{x} \mathrm{~F}_{2+x}$ nanopowders (3). Straight-line dependence according to Fedorov and Sobolev [55]

have come from 8 wt. \% loss from decomposition:

$$
\left(\mathrm{H}_{3} \mathrm{O}\right) \mathrm{Y}_{3} \mathrm{~F}_{10} \rightarrow 3 \mathrm{YF}_{3}+\mathrm{H}_{2} \mathrm{O}+\mathrm{HF}
$$

along with additional evaporation of hydration water from the solid sample.

Structure of $\mathrm{KY}_{3} \mathrm{~F}_{10}$ type is derived from fluorite. It consists of a $3 \mathrm{D}$ framework formed by $\left(\mathrm{Y}_{6} \mathrm{~F}_{35}\right)^{18-}$ clusters (Fig. 2) interconnected by their vertices. Monovalent cations occupy cavities of the aforementioned framework [14,55,56]. $\quad \mathrm{KR}_{3} \mathrm{~F}_{10}(\mathrm{R}=\mathrm{Dy}-\mathrm{Lu}, \mathrm{Y})$ and $\mathrm{RbR}_{3} \mathrm{~F}_{10}(\mathrm{R}=\mathrm{Sm}-\mathrm{Tb})$ [3] crystallize in this structure type. However, the structure for $\mathrm{KY}_{3} \mathrm{~F}_{10}$ can also can be described as a $3 \mathrm{D}$ framework of $\left(\mathrm{Y}_{6} \mathrm{~F}_{32}\right)^{14-}$ clusters (constructed from Thompson antiprism coordination yttrium polyhedra in another way) [57] that are also present in the structure of $\left(\mathrm{H}_{3} \mathrm{O}\right) \mathrm{Y}_{3} \mathrm{~F}_{10} \mathrm{nH}_{2} \mathrm{O}$ phase $(F d 3 m$ SSG, $Z=16)$ [36]. However, the latter clusters are packed in a different manner, and the previously described $\left(\mathrm{H}_{3} \mathrm{O}\right) \mathrm{Y}_{3} \mathrm{~F}_{10} \mathrm{nH}_{2} \mathrm{O}$ phase $(F d 3 m \mathrm{SSG}, Z=16)$ is not a fluorite-type phase, in contrast with the phase obtained in our experiments for $90 \% \mathrm{YF}_{3}-10 \% \mathrm{CaF}_{2}$ solid solution specimen (Table 2).

The above results for the $\mathrm{CaF}_{2}-\mathrm{YF}_{3}$ system, obtained by co-precipitation method, are similar to our data for the $\mathrm{CaF}_{2}-\mathrm{HoF}_{3}$ system [54]. They are also in a good agreement with data [43] regarding $\mathrm{Ca}_{1-x} \mathrm{R}_{x} \mathrm{~F}_{2+x}$ solid solutions. Weak additional lines in the $\mathrm{X}$-ray diffraction patterns, corresponding to $\beta-\mathrm{YF}_{3}$ nanoparticles, were also observed for $\mathrm{Ca}_{0.6} \mathrm{Y}_{0.4} \mathrm{~F}_{2.4}$, also synthesized by the aforementioned co-precipitation in [45].

It is also worth mentioning that we did not observe the formation of tysonite-type phase(s) in the co-precipitated specimens at the lower temperatures. This should not be surprising if one takes into account that such a tysonitetype phase is stable at higher temperatures only (Fig. 1). Nevertheless, it is quite strange that there was no fluorite-type solid solutions formed in the $\mathrm{CaF}_{2}-\mathrm{RF}_{3}$ systems $(\mathrm{R}=$ rare earth element) that contain a relatively high concentration of the rare earth metals (35-40 mol. \% $\mathrm{RF}_{3}$ ) and possess ordered fluorite-type structures (such ordered phases are usually thermodynamically stable at the lower temperatures). The other previously studied $\mathrm{MF}_{2}-\mathrm{RF}_{3}$ systems (e.g., $\mathrm{SrF}_{2}-\mathrm{YF}_{3}$ [53], $\mathrm{BaF}_{2}-\mathrm{YF}_{3}$ [49], $\mathrm{BaF}_{2}-\mathrm{CeF}_{3}$ [52]) with $\mathrm{M}=\mathrm{Sr}$ and Ba have exhibited different features: each of these systems had the concentration ranges, where ordered fluorite-type phases were observed under equilibrium conditions at the higher temperatures, the unordered solid solutions were formed. Currently, it is hard to find a reasonable explanation for the different results for calcium fluoride systems.

In conclusion, results of our study demonstrate that in the course of the synthesis of $\mathrm{Ca}_{1-x} \mathrm{Y}_{x} \mathrm{~F}_{2+x}$ solid solutions by co-precipitation from aqueous media, the single phase specimens have been formed for the relatively low yttrium content only (up to $20 \mathrm{~mol}$. $\% \mathrm{YF}_{3}$ ). These samples, apparently, are not under equilibrium, but they 
are fairly stable and do not undergo any detectable changes over the course of a few years. The latter is crucially important for the preparation of materials of practical value [58].

\section{Acknowledgments}

The authors express their appreciation to R. Ermakov for his kind assistance in the X-ray diffraction experiments as well as to V.K. Ivanov for his valuable discussion of the obtained results. The authors also wish to thank E. V. Chernova and A. I. Popov for their help in the preparation of the present manuscript.

This work was partially supported by RFBR 15-08-02481-a grant.

\section{References}

[1] Thoma R.E., Hebert G.M., Insley H., Weavwe C.F. Phase equilibria in the system sodium fluoride-yttrium fluoride. Inorg. Chem., 1963, 2(5), P. 1005-1012.

[2] Fedorov P.P., Sobolev B.P., Belov S.F. Fusibility diagram of the system $\mathrm{NaF}_{-} \mathrm{YF}_{3}$, and the cross-section $\mathrm{Na}_{0.4} \mathrm{Y}_{0.6} \mathrm{~F}_{2.2}-\mathrm{YOF}_{\text {Inorg }}$. Mater, 1979, 15(5), P. 640-643.

[3] Fedorov P.P. Systems of alcali and rare-earth metal fluorides. Russian J. Inorg. Chem., 1999, 44(11), P. $1703-1727$.

[4] Fedorov P.P., Kuznetsov S.V., Osiko V.V. Elaboration of nanofluorides and ceramics for optical and laser applications. Chapter in the book Photonic \& Electronic Properties of Fluoride Materials, Ed. Tressaud A., Poeppelmeier K., Amsterdam et al.: Elsevier, 2016 , P. 7-31.

[5] Fedorov P.P. Heterovalent isomorphism and solid solutions with a variable number of ions in the unit cell. Russ. J. Inorg. Chem., 2000, 45, Suppl. 3, P. S268-S291.

[6] Vogt T. Uber die Flusspat-Yttrofluoritgruppe. Neues Jahrb. Mineral, 1914, 2(1), P. 9-13.

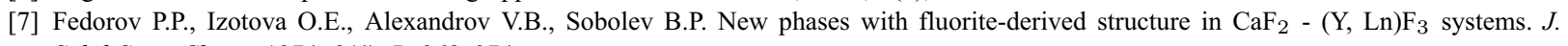
Solid State Chem., 1974, 9(4), P. 368-374.

[8] Seiranian K.B., Fedorov P.P., Garashina L.S., Molev G.V., Karelin V.V., Sobolev B.P. Phase diagram of the system CaF 2 -YF 3. J. Crystal Growth, 1974, 26(1), P. 61-64.

[9] Crystals with the fluorite structure. Ed. Hayes W. Oxford: Clarendon Press, 1974, 448 pp.

[10] Fedorov P.P., Sobolev B.P. Variable-composition phases with the $\mathrm{LaF}_{3}$ structure in the systems $\mathrm{MF}_{2}-\left(\mathrm{Y}, \mathrm{Ln}_{)} \mathrm{F}_{3}\right.$. II. The systems CaF 2 $(\mathrm{Y}, \mathrm{Ln}) \mathrm{F}_{3}$ (thermal characteristics and formation of berthollides). Kristallografiya, 1975, 20(5), P. 584-586.

[11] Sobolev B.P., Aleksandrov V.B., Fedorov P.P., et al. Variable-composition phases with the LaF $\mathrm{L}_{3}$ structure in the systems MF $2-\left(\mathrm{Y}_{\text {,Ln }} \mathrm{F}_{3}\right.$. IV. X-ray characteristics, heterovalent isomorphic substitutions. Kristallografiya, 1976, 21(1), P. 49-54.

[12] Gettmann W., Greis O. Uber fluorit- und tysonitverwandte Ordnungsphasen im System CaF $2-\mathrm{YF}_{3}$. J. Solid State Chem., 1978, 26(2), P. 255-263.

[13] Kaminskii A.A. Laser crystals: their physics and properties. Berlin, Heidelberg: Springer Verlag, 1990,459 pp.

[14] Greis O., Hashke J.M. Rare earth fluorides. In Handbook on the Physics and Chemistry of Rare Earth. Amsterdam: Elsevier, 1982, v.5, P. $387-460$.

[15] Kuntz A.F. Fluorite crystallization under hydrothermal conditions. Proc. of Geology Institute, Komi department of USSR Academy of Sciences, 1982, 39, P. 31-41. (in Russian)

[16] Otroshchenko L.P., Aleksandrov V.B., Bydanov N.N., Simonov V.I., Sobolev B.P. Neutron-diffraction structure refinement of the $\mathrm{Ca}_{0.90} \mathrm{Y}_{0.10} \mathrm{~F}_{2.10}$ solid solution. Kristallografiya, 1988, 33(3), P. 764-765. (in Russian)

[17] Ivanov-Shits A.K., Sorokin N.I., Fedorov P.P., Sobolev B.P. Specific features of ionic transport in nonstoichiometric fluorite-type $\mathrm{Ca}_{1-x} \mathrm{R}_{x} \mathrm{~F}_{2+x}(\mathrm{R}=\mathrm{La}-\mathrm{Lu}, \mathrm{Y}, \mathrm{Sc})$ phases. Solid State Ionics, 1990, 37, P. 125-137.

[18] Sobolev B.P. The rare earth trifluorides. Part 1. The high temperature chemistry of the rare earth trifluorides. Barcelona: Institut d'Estudis Catalans, 2000, 520 pp.

[19] Sobolev B.P. The rare earth trifluorides. Part 2. Introduction to materials sience of multicomponent metal fluoride crystals. Barcelona: Institut d'Estudis Catalans, 2001, $459 \mathrm{pp}$.

[20] Karimov D.N., Krivandina E.A., Zhmurova Z.I., Sobolev B.P., Bezhanov V.A., Chernov S.P., Shapochkin G.M. Investigation of multicomponent fluoride optical materials in the UV spectral region: I. Single crystals of $\mathrm{Ca}_{1-x} \mathrm{R}_{x} \mathrm{~F}_{2+x}(\mathrm{R}=\mathrm{Sc}, \mathrm{Y}, \mathrm{La}, \mathrm{Yb}, \mathrm{Lu})$ solid solutions. Crystallogr. Rep., 2006, 51(6), P. 1009-1015.

[21] Fedorov P.P. Third law of thermodynamics as applied to phase diagrams. Russ. J. Inorg. Chem., 2010, 55(11), P. 1722-1739.

[22] Bolotina N.B., Kalyukanov A.I., Chernaya T.S., Verin I.A., Buchinskaya I.I., Sorokin N.I., Sobolev B.P. X-ray and neutron diffraction study of the defect crystal structure of the as-grown nonstoichiometric phase $\mathrm{Y}_{0.715} \mathrm{Ca}_{0.285} \mathrm{~F}_{2.715}$. Crystallogr. Rep., 2013, 58(4), P. 575-585.

[23] Popov P.A., Fedorov P.P., Osiko V.V. Thermal conductivity of single crystals of the $\mathrm{Ca}_{1-x} \mathrm{Y}_{x} \mathrm{~F}_{2+x}$ solid solution. Doklady Physics, 2014, 59(5), P. 199-202.

[24] Krahl T., Scholz G., Kemnitz E. Solid Solutions $\mathrm{CaF}_{2}-\mathrm{YF}_{3}$ with fluorite structure prepared on the solgel route: investigation by multinuclear MAS NMR spectroscopy. J. Phys. Chem. C, 2014, 118, P. 21066-21074.

[25] Bergstol S., Jensen B.B., Neuman H. Tveitite, a new calcium yttrium fluoride. Lithos, 1977, 10, P. 81-87.

[26] Bevan D.J.M., Strahle J., Greis O. The crystal structure of tveitite, an ordered yttrofluorite mineral. J. Solid State Chem., 1982, 44, P. $75-81$.

[27] Atencio D., Bastos Neto A.C., Pereira V.P., et al. Waimirite-(Y), orthorhombic YF 3 , a new mineral from the Pitinga mine, Presidente Figueiredo, Amazonas, Brazil and from Jabal Tawlah, Saudi Arabia: description and crystal structure. Mineral. Magazine, 2015, 79(3), P. 767-780.

[28] Fedorov P.P. Association of point defects in non stoichiometric $\mathrm{M}_{1-x} \mathrm{R}_{x} \mathrm{~F}_{2+x}$ fluorite-type solid solutions. Butll. Soc. Cat. Cien., 1991, 12(2), P. 349-381.

[29] Kazanskii S.A., Ryskin A.I., Nikiforov A.E., Zaharov A.Yu., Ougrumov M.Yu., Shakurov G.S. EPR spectra and crystal fleld of hexamer rare-earth clasters in fluorites. Phys. Rev. B, 2005, 72, 014127 P. 1-11. 
[30] Popov P.A., Dykel'skii K.V., Mironov I.A., Demidenko V.A., Smirnov A.N., Smolyanskii P.L., Fedorov P.P., Osiko V.V., Basiev T.T., Thermal conductivity of $\mathrm{CaF}_{2}$ optical ceramics. Doklady Physics, 2007, 52(1), P. 7-9.

[31] Turkina T.M., Fedorov P.P., Sobolev B.P. Stability of plane crystallization front in growth of single crystals of solid solutions $\mathrm{M}_{1-x} \mathrm{R}_{x} \mathrm{~F}_{2+x}$ (where $\mathrm{M}=\mathrm{Ca}, \mathrm{Sr}, \mathrm{Ba}, \mathrm{R}=$ rare earth) from a melt Kristallografiya, 1986, 31(1), P. 83-87.

[32] Kuznetsov S.V., Fedorov P.P. Morphological Stability of Solid-Liquid Interface during Melt Crystallization of Solid Solutions $\mathrm{M}_{1-x} \mathrm{R}_{x} \mathrm{~F}_{2+x}$. Inorg. Mater, 2008, 44(13), P. 1434-1458. (Supplement)

[33] Sobolev B.P., Fedorov P.P. Hexagonal $\mathrm{YF}_{3}$ ' structure type and high-temperature modifications of rare-earth trifluorides isostructural with $\mathrm{YF}_{3}$. Kristallografiya, 1973, 18(3), P. 392.

[34] Kuznetzov S.V., Osiko V.V., Tkatchenko E.A., Fedorov P.P. Inorganic nanofluorides and related nanocomposites. Russian Chem. Rev., 2006, 75(12), P. 1065-1082.

[35] Fedorov P.P., Luginina A.A., Kuznetsov S.V., Osiko V.V. Nanofluorides. J. Fluorine Chem., 2011, 132(12), P. 1012-1039.

[36] Lucier B.E.G., Johnston K.E., Arnold D.C., et. al. Comprehensive Solid-State Cheracterization of Rare Earth Fluoride Nanoparticles. J. Phys. Chem. C, 2014, 118(2), P. 1213-1228.

[37] Van Veggel F.C.J.M. Upconversion of $\mathrm{Ln}^{3+}$-based Nanoparticles for Optical Bio-imaging. In: Luminescence of Lanthanide Ions in Coordination Compounds and Nanomaterials. John Wiley Sons, 2014, P. 269-302.

[38] Fedorov P.P., Luginina A.A., Popov A.I. Transparent Oxyfluoride Glass Ceramics. J. Fluorine Chem., 2015, 172, P. 22-50.

[39] Naccache R., Yu Q., Capobianco J.A. The fluoride host: nucleation, growth, and upconversion of lanthanide-doped nanoparticles. Adv. Optical Mater., 2015, 3(4), P. 482-509.

[40] Düvel A., Bednarcik J., Šepelák V., Heitjans P. Mechanosynthesis of the fast fluoride ion conductor $\mathrm{Ba}_{1-x} \mathrm{La}_{x} \mathrm{~F}_{2+x}$ : from the fluorite to the tysonite structure. J. Phys. Chem. C, 2014, 118, P. 7117-7129.

[41] G. Scholz, S. Breitfeld, T. Krahl, A. Düvel, P. Heitjans, E. Kemnitz. Solid State Sciences, 2015, 50, P. 32-41.

[42] Lei Lei, Daqin Chen, Feng Huang, Yunlong Yu, Yuansheng Wang. J. Alloys Comp., 2012, 540, P. $27-31$.

[43] Kouznetzov S.V., Yarotskya I.V., Fedorov P.P., Voronov V.V., Lavristchev S.V., Basiev T.T., Osiko V.V. Preparation of Nanopowdered $\mathrm{M}_{1-x} \mathrm{R}_{x} \mathrm{~F}_{2+x}(\mathrm{M}=\mathrm{Ca}, \mathrm{Sr}, \mathrm{Ba} ; \mathrm{R}=\mathrm{Ce}, \mathrm{Nd}, \mathrm{Er}, \mathrm{Yb})$ Solid Solutions. Russian J. Inorg. Chem., 2007, 52, P. 315-320.

[44] Fedorov P.P., Kuznetsov S.V., Voronov V.V., Yarotskya I.V., Arbenina V.V. Soft chemical synthesis of NaYF 4 nanopowders. Russian J. Inorg. Chem., 2008, 53(11), P. 1681-1685.

[45] Fedorov P.P., Kuznetsov S.V., Mayakova M.N., et al. Coprecipitation from aqueous solutions to prepare binary fluorides. Russian J. Inorg. Chem., 2011, 56(10), P. 1525-1531.

[46] Luginina, A.A., Fedorov, P.P., Kuznetsov, S.V., et al., Synthesis of ultrafine fluorite $\operatorname{Sr}_{1-x} \mathrm{Nd}_{x} \mathrm{~F}_{2+x}$ powders. Inorg. Mater., 2012, 48(5), P. 531-538.

[47] Kuznetsov, S.V., Ovsyannikova, A.A., Tupitsyna, E.A., Yasyrkina, D.S., Voronov, V.V., Fedorov, P.P., Batyrev, N.I., Iskhakova, L.D., Osiko, V.V. Phase formation in $\mathrm{LaF}_{3}-\mathrm{NaGdF}_{4}, \mathrm{NaGdF}_{4}-\mathrm{NaLuF}_{4}, \mathrm{NaYF}_{4}-\mathrm{NaLuF}_{4}$ systems: synthesis of powders by co-precipitation from aqueous solutions. J. Fluor. Chem., 2014, 161, P. 95-101.

[48] S.V. Kuznetsov, D.S. Yasyrkina, A.V. Ryabova, D.V. Pominova, V.V. Voronov, A.E. Baranchikov, V.K. Ivanov, P.P. Fedorov. $\alpha$ $\mathrm{NaYF}_{4}: \mathrm{Yb}: \mathrm{Er} @ \mathrm{AlPc}\left(\mathrm{C}_{2} \mathrm{O}_{3}\right)_{4}$-Based efficient up-conversion luminophores capable to generate singlet oxygen under IR excitation. $J$. Fluor. Chem., 2016, 182, P. 104-108.

[49] Fedorov P.P., Mayakova M.N., Kuznetsov S.V., Voronov V.V., Ermakov R.P., Samarina K.S., Popov A.I., Osiko V.V. Co-Precipitation of yttrium and barium fluorides from aqueous solutions. Mat. Res. Bull., 2012, 47, P. 1794-1799.

[50] Fedorov P.P., Mayakova M.N., Kuznetsov S.V., Voronov V.V., Osiko V.V., Ermakov R.P., Gontar' I.V., Timofeev A.A., Iskhakova L.D. Coprecipitation of barium-bismuth fluorides from aqueous solutions: nanochemical effects. Nanotechnologies in Russia, 2011, 6, P. 203-210.

[51] Mayakova M.N., Kuznetsov S.V., Voronov V.V., Baranchikov A.E., Ivanov V.K., Fedorov P.P. Soft chemistry synthesis of powders in the $\mathrm{BaF}_{2}-\mathrm{ScF}_{3}$ system. Russian J. Inorg. Chem., 2014, 59(7), P. 773-777.

[52] Mayakova M.N., Voronov V.V., Iskhakova L.D., Kuznetsov S.V., Fedorov P.P. Low-temperature phase formation in the BaF 2 -CeF $_{3}$ system. J. Fluorine Chem., 2016, 187, P. 33-39.

[53] Mayakova M.N., Luginina A.A., Kuznetsov S.V., Voronov V.V., Ermakov R.P., Baranchikov A.E., Ivanov V.K., Karban' O.V., Fedorov P.P. Synthesis of $\mathrm{SrF}_{2}-\mathrm{YF}_{3}$ nanopowders by co-precipitation from aqueous solutions. Mendeleev Communications, $2014,24(6)$, P. 360-362.

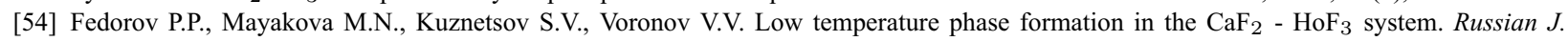
Inorg. Chem., 2017, 62(9), P. 1173-1176.

[55] Fedorov P.P., Sobolev B.P. Concentration dependence of unit-cell parameters of phases $\mathrm{M}_{1-x} \mathrm{R}_{x} \mathrm{~F}_{2+x}$ with the fluorite structure. Sov. Phys. Crystallogr, 1992, 37(5), P. 651-656.

[56] Ayala F.P., Oliveira M.A.S., Gesland J.-Y., Moreira R.L. Electrical and dielectrical investigation of the conduction processes in KY $\mathrm{F}_{10}$ crystals. J. Phys. C.: Condensed Matter, 1998, 10, P. 5161-5170.

[57] Podberezskay N.V., Potapova O.G., Borisov S.V., Gatilov Yu. V. KTb $\mathrm{F}_{10}$ crystal structure - cubic pacing of [Tb $\left.\mathrm{F}_{32}\right]^{14-}$ polyanions. $J$. Struct. Chem., 1976, 17(5), P. 948-950. (in Russian)

[58] Vahrenev R.G., Mayakova M.N., Kuznetsov S.V., Ryabova A.V., Pominova D.V., Voronov V.V., Fedorov P.P. The research of synthesis and luminescent characteristics of calcium fluoride doped with ytterbium and erbium for biomedical application. Condensed Media and Interface Borders, 2016, 18(4), P. 478-484. 